\title{
Using Bloom's taxonomy to evaluate the cognitive levels of Primary Leaving English Exam questions in Rwandan schools
}

\author{
Théophile Muhayimana ${ }^{1} \cdot$ Lambert Kwizera $^{2} \cdot$ Marie Rose Nyirahabimana $^{3}$
}

Received: 13 August 2021 / Revised: 15 December 2021 / Accepted: 19 December 2021 / Published online: 19 January 2022

(c) The Author(s) under exclusive licence to Australian Curriculum Studies Association 2022

\begin{abstract}
This qualitative study investigates the cognitive levels of the questions used in the English primary six leaving examinations administered in Rwandan schools from 2013 to 2019. We used the revised Bloom's Taxonomy to scrutinize the cognitive levels of 574 exam questions. The findings revealed a remarkable predominance of the lower-order thinking skills (LOTS) (98.79\%) over the higher-order thinking skills (HOTS) exam questions (1.21\%). The study addresses the gap in the current literature on high-stake and accountability-driven assessment practices regarding the language educational policies involving the use of English as a classroom language and curriculum reforms in postcolonial contexts. In particular, the study provides education practitioners and decision-makers with a body of knowledge conducive to writing high-quality exams that are likely to boost effective instruction and higher student learning and success in schools and beyond.
\end{abstract}

Keywords Assessment $\cdot$ Curriculum $\cdot$ Postcolonial context $\cdot$ Revised Bloom's taxonomy

\section{Introduction}

Assessment is an important tool to evaluate the teaching and learning process for improvement purposes (Nykowanna, 2019). In broader terms, assessment helps schools judge and decide about excellent conditions of student learning as well as the quality and effectiveness of instruction (Jones et al., 2009; Tosuncuoglu, 2018). In this context, Bloom devised a taxonomy used to develop assessments that consider each of the six levels of hierarchy in the cognitive domain (Ramirez, 2017). Lower-order thinking domains include knowledge (recalling details), comprehension (description in

Théophile Muhayimana

muhayimt@uni.edu

Lambert Kwizera

lambertkwizera@gmail.com

Marie Rose Nyirahabimana

nyizera@yahoo.fr

1 Department of Educational Psychology, Foundations, and Leadership Studies, University of Northern Iowa, 1227 W 27th St, Cedar Falls, IA 50614, USA

2 University of Rwanda, KK 737 Street, Gikondo, Kigal, P.O BOX 4285, Kigali, Rwanda

3 Ecole Primaire St Vincent de Paul, P.O Box 6841, Kigali, Rwanda somebody's words), and application (using existing knowledge to produce results). Higher-order thinking domains encompass analysis (finding out links between facts and concepts), synthesis (producing a new original work), and evaluation (judging and showing one's position) (Deller, 2019; Freahat \& Smadi, 2014).

Scholars used the two cognitive categories of Bloom's taxonomy to analyze and determine the levels of questions asked in exams, and they established two types, namely lower-level questions (LLQs) and higher-level questions (HLQs) (Ramirez, 2017). The LLQs focus on the recall of fundamental and universal concepts and processes. On the other hand, the HLQs are well advanced and challenging because they require students to engage in deeper and analytical thinking processes (Assaly \& Smadi, 2015; Pendergast \& Swain, 2013; The Learning Center, 2020). The level of student thinking activities during both instruction and exams is critical for their intellectual abilities, higher performance, and professional success. As a result, exams should be designed to encourage students to give opinions about the exam questions, form creative answers, and relate the exam answers with their own experiences and real-life situations (Assaly \& Smadi, 2015; Sydoruk, 2018).

Hence, writing high-quality exams that include both HLQs and LLQs plays a crucial role in helping students achieve the target learning outcomes and evaluate their level 
of proficiency in a specific course (Wachiuri et al., 2017). The HLQs help students deepen the learning materials and promote their critical thinking mindset and creativity. In this vein, Song (2019) claimed there is a positive relationship between teacher's questions and students' critical thinking. In the same line of thought, Wagner (2011) underscored that high-quality education should infuse the seven survival skills at higher-level thinking. Daggett (2016) echoed Wagner's views and indicated that beyond knowledge and remote learning, schools must emphasize the higher-order skills to develop critical thinking citizens through higherorder materials.

Therefore, the present study seeks to examine the degree to which the questions of the Primary Leaving Examinations in the English subject prepared by the Rwanda Education Board include both higher and lower-order thinking levels. In the first place, it is essential to assess how well students master the information within the six levels of the taxonomy. In a step further, it is critical to analyze whether the exam questions of the national Primary Leaving Examinations in the English courses are based on both higher and lower-order thinking levels.

\section{Context of the study}

As a Belgian colony, Rwanda has used French as the medium of instruction and language of administration from the colonial period (1916) up to 1994 (Kayigema \& Mutasa, 2014). In December 2008, the government declared that English would replace French as the teaching language, and the decision became effective in January 2009. In 2015, the government launched a competency-based curriculum in substitution of a knowledge-based curriculum (Ndihokubwayo et al., 2019; Ngendahayo \& Askell-Williams, 2016).

The Rwanda Education Board (REB) viewed the new language of instruction and the curriculum reform as practical tools to provide Rwandan students with the skills and competencies they need to become entrepreneurial as well as locally and internationally innovative (Ndihokubwayo \& Habiyaremye, 2018). Thus, the government believed that skilled citizens could help the country become an economic hub in central Africa and make a giant leap towards becoming an African Singapore (Krikorian, 2019; The World Bank \& Government of Rwanda, 2018).

First, English would place Rwandan learners in a better position to exploit job and business opportunities at local and international levels (Euromonitor International, 2010). That is why the government decided to use English as the language of instruction from Primary four (fourth grade) onwards. Second, along with English as a classroom language in 2008, the REB launched the competency-based curriculum in 2015 because authorities believed it was conducive to promoting a skills-based economy (Government of Rwanda, 2020).

Third, the REB hoped the CBC would promote generic and intersecting competencies such as critical thinking, creativity, problem-solving, communication, interpersonal relations, life skills, and life-long learning. The REB thought such competencies would enable students to become lifelong learners who can adapt to the fast-changing world and the uncertain future (Ngendahayo \& Askell-Williams, 2016; Rwanda Education Board, 2015a).

Currently, many countries all over the world have adopted a competency-based curriculum (CBC) since its inception in the 1970s in the USA (Sifuna and Obonyo, 2019). Germany and Australia introduced the CBC in their education system in the 1980s and the 1990s, respectively, while England rolled it out in 2008-2010 (Anderson-Levitt, 2017; Nsengimana, 2021). The province of Quebec adopted competency-based approaches in 2001, and the Canadian central government reformed the K-12 curricula by incorporating competencies beginning in 2015 (Christensen \& Lane, 2016). In Asia, Singapore implemented CBC in 2010, and China enacted the CBC in 2013 (Rajandiran, 2021; Wang, 2019). In Latin America, Mexico introduced the CBC in 2004, and Brazil initiated it in 2013 (Anderson-Levitt, 2017; Costin \& Pontual, 2020).

The concept of CBC has recently also gained popularity in Africa, and this curriculum reform is implemented in different parts of the continent in an effort to attain quality education and ensure that learning leads to high standards and levels of performance (Ruth \& Ramadas, 2019; Sifuna \& Obonyo, 2019). Some African countries such as Botswana, Cameroon, Senegal, and South Africa rolled out the same curriculum that underscores authentic assessment strategies and promotes competencies and the use of knowledge and skills in real-life situations (Ruth \& Ramadas, 2019; Sifuna \& Obonyo, 2019). More specifically, in the East Africa Community where Rwanda is a member state, Tanzania and Kenya adopted the CBC in 2005 and 2017 respectively to better empower learners with skills and attitudes they need for job market competitiveness in the twenty-first century (Ondimu, 2018).

Several situational factors contribute to effective implementation of competency-based approaches such as sufficient resources, culture, and traditions, as well as equity and quality (Ryan et al., 2009). Other elements key to success are teacher awareness and attitudes on curriculum changes and collaboration among CBC implementors (Dlamini et al., 2018; Nsengimana, 2021; Scheopner Torres et al., 2018). Unfortunately, such laudable efforts seeking to take a similar economic and social development path as Rwanda faced multiple challenges. They include lack of teacher preparedness and training on the new curriculum, mismatching between the content and 
pedagogical practices, poor public participation and haphazard CBC implementation, and lack of approved textbooks for learners (Akala, 2021; Sifuna \& Obonyo, 2019). Additionally, Ruth and Ramadas (2019) indicated that there has been lack of contextualization of CBC implementation, limited understanding of $\mathrm{CBC}$ objectives, and its implementation with fidelity (Kafyulilo et al., 2013; Komba \& Mwandaji, 2015).

For proper mastery and implementation of the competency-based curriculum, the Government of Rwanda initiated the District Continuous Professional Development Committees (DCCs) in July 2016, which later on in January 2017 culminated in Sector/School-based Continuous Professional Development Committees (SCCs) (Rwanda Education Board, 2019). The ultimate mandate of SCCs is to enable teachers to develop professionally to achieve quality teaching and learning by improving classroom practice as stipulated in the new curriculum (Rwanda Education Board, 2019). It is claimed that the most significant opportunity for SCCs for teachers is at the school level, where they can frequently engage with each other to support improvement in practice (Rwanda Education Board, 2019).

\section{Problem statement}

The design and formulation of a curriculum as a policy is the initial phase of the process. The implementation with fidelity is another yet critical step that needs to look into the degree to which such high-standards goals in books are being attained in schools through effective instructional and assessment practices (Makunja, 2016; Tabaro, 2018). Hence, upon the implementation of the $\mathrm{CBC}$, it is crucial to examine the extent to which primary leaving examinations are on the path towards competencies using the Bloom's taxonomy approach.

More specifically, this study intends to analyze the Primary Leaving English Examinations (PLEEs) by scrutinizing the cognitive domain levels according to the Bloom's taxonomy framework. The REB (2015b) emphasized that, within the CBC framework, examiners should give questions from the higher levels of Bloom's taxonomy more weight than those from the knowledge and comprehension level. In addition, the REB recommended that examiners must ensure questions do not require memorization or recall answers only but test for broad competencies as stated in the syllabus (Gottipati \& Shankararaman, 2017). In other words, the REB urged examiners to place more importance or weight on questions that indicate or reflect higher desired competencies (Rwanda Education Board, 2015b).

\section{Research question}

This study investigates the cognitive levels of the questions used in the English primary six leaving examinations for all schools in Rwanda administered nationwide from 2013 to 2019. We thus put forward the following research question: To what extent do English primary six leaving examination questions cover the lower and higher-order cognitive levels of Bloom's taxonomy?

\section{Needs and significance of the study}

The purpose of the study is to identify the degree to which the PLEEs questions included both higher and lower-order cognition levels of Bloom's taxonomy. The study is the first of its nature that investigates the cognitive level of the questions in primary six English exams in Rwanda. Most literature on assessment in Rwandan education has mainly focused on higher education (Bahati et al., 2016; Mugisha, 2010; Tabaro, 2017). A handful of studies have investigated assessment in secondary schools only (Ndihokubwayo et al., 2020; Ngendahayo \& Askell-Williams, 2016; Sibomana, 2016). As mentioned earlier, Rwanda embarked on highstakes educational reforms involving the switch from French to the English language as a classroom language in 2008 and the implementation of the CBC in 2015 (Ndihokubwayo et al., 2020). Since the inception of the two high-stakes policies, there has been no empirical study on assessment practices regarding teaching English as a foreign language (EFL) in primary schools.

Thus, this study will be the trailblazing empirical investigation of EFL assessment practices in upper primary schools. More specifically, the work will be helpful to a wide range of people, including the REB and other government decision-makers in education, school leaders, and teachers. The study will also benefit the research community interested in evaluating student learning outcomes in general and assessment practices regarding curricular reforms and language education policies involving teaching EFL in postcolonial contexts.

\section{Literature review}

\section{Bloom's Taxonomy of educational objectives}

The most common taxonomy used in education is that of Bloom (Krathwohl, 2002; Wilson, 2016). He created this taxonomy in 1956, and it is a hierarchical listing of thinking. Among other countless uses, the taxonomy 
helps instructors to teach and students to learn. Bloom's taxonomy is a popular tool used in educational services to develop assessments that measure the six cognitive levels (Deller, 2019). Bloom's taxonomy has been used in several studies that aimed to assess the languages (Köksal \& Ulum, 2018; Pikhart \& Klimova, 2019), student learning outcomes and course exam questions (Welch et al., 2017), school curriculum (Koç \& Öntaş, 2020), and school workbooks (Uğur, 2019). Bloom's taxonomy has also been a tool to investigate the type and the cognitive level of the textbooks' questions and a guide to classify questions (Zorluoglu et al., 2020).

Krathwohl (2002) revised the initial taxonomy by removing the "Synthesis" and including the "Creation" level as the highest category. He came up with six cognitive skills including remembering, understanding, applying, analyzing, evaluating, and creating. (Armstrong, 2010; Pendergast \& Swain, 2013; Wilson, 2016). As indicated in Table 1, these revised Bloom's taxonomy cognitive domain levels are divided into two levels. Higher-Order Thinking Skills (HOTS) comprise creating, evaluating, and analyzing. Lower-Order Thinking Skills (LOTS) include applying, understanding, and remembering. Table 1 visualizes the revised Bloom's taxonomy levels ordered step by step from down to top.

The revised Bloom's taxonomy has been used as a framework to assess language learning (Köksal \& Ulum, 2018; Rosell-Aguilar, 2017), English curricula (Arvianto et al., 2020), and English examination or English question papers (Al-Khayyat, 2020). Hence, understanding the revised Bloom's taxonomy is critical for writing high-quality English examination questions that test all required cognitive skills to reflect the target competencies.

\section{Assessment and washback effect}

Good questions do not only stimulate effective learning and assessment, but they must also align with curriculum and instruction because assessment greatly influences both learning and teaching. The phenomenon is described as washback effect, and it refers to the impact of testing on teaching and learning (Sundayana et al., 2018). This effect influences the attitudes, behaviors, and motivation of teachers, learners, and parents either in a positive or in a negative manner (Elshawa et al., 2016; Sundayana, et al., 2018). When this effect enhances teaching quality and student learning, the effect is positive, which is a sign of good teaching practices. Conversely, the negative washback is due to the structure of content or format of the course or exam designed in a narrow and partial way (Elshawa et al., 2016). This implies that proper planning of effective assessment is essential for effective teaching and learning (Tosuncuoglu, 2018). Therefore, drafting good exam questions requires critical attention to the effect of assessment on both teaching quality and student learning outcomes.

To achieve this goal, Pendergast and Swain (2013) recommended the alignment of the curriculum, instruction, and assessment. Based on constructive alignment principles, assessment tasks, teaching, and learning experiences must be linked to the desired curriculum learning outcomes. Therefore, Pendergast and Swain (2013) go on to urge that teaching and learning experiences should mirror the assessment tasks content in order to prepare leaners appropriately for what is anticipated in the exams.

\section{Sustainable assessment for life-long learning}

Traditional classroom assessment has long focused on evaluating the instructional quality and measurement of student learning outcomes (Andrade \& Brookhart, 2020).

Table 1 Cognitive domain levels of the revised Bloom's taxonomy

\begin{tabular}{|c|c|c|c|c|}
\hline Cognitive levels & Cognitive domains & Definitions & Examples & Illustrative action verbs \\
\hline \multirow[t]{3}{*}{ High order } & Creating & $\begin{array}{l}\text { Craft or produce a new idea, a } \\
\text { new original work }\end{array}$ & $\begin{array}{l}\text { Develop a website using Java as } \\
\text { the programming language }\end{array}$ & $\begin{array}{l}\text { Build, create, develop, modify, } \\
\text { plan }\end{array}$ \\
\hline & Evaluating & $\begin{array}{l}\text { Judge and decide based on crite- } \\
\text { ria, information, and norms }\end{array}$ & $\begin{array}{l}\text { Justify your ranking of the prod- } \\
\text { ucts based on the set standards }\end{array}$ & $\begin{array}{l}\text { Argue, critique, weigh, judge, } \\
\text { justify, rank, support }\end{array}$ \\
\hline & Analyzing & $\begin{array}{l}\text { Identify or find out links between } \\
\text { evidence, ideas, facts, and } \\
\text { concepts }\end{array}$ & $\begin{array}{l}\text { Compare traveling by bus with } \\
\text { flying }\end{array}$ & $\begin{array}{l}\text { Contrast, differentiate, distinguish, } \\
\text { relate }\end{array}$ \\
\hline \multirow[t]{3}{*}{ Low order } & Applying & $\begin{array}{l}\text { Utilize knowledge or informa- } \\
\text { tion in different scenarios or } \\
\text { situations }\end{array}$ & $\begin{array}{l}\text { Provide orientation to new } \\
\text { students }\end{array}$ & $\begin{array}{l}\text { Demonstrate, execute, implement, } \\
\text { operate }\end{array}$ \\
\hline & Understanding & $\begin{array}{l}\text { Process or explain evidence, } \\
\text { facts, ideas, and concepts }\end{array}$ & Explain the carbon cycle & $\begin{array}{l}\text { Classify, determine, explain, iden- } \\
\text { tify, process }\end{array}$ \\
\hline & Remembering & $\begin{array}{l}\text { Recall pieces of evidence, facts, } \\
\text { ideas, and concepts }\end{array}$ & $\begin{array}{l}\text { List the symptoms of COVID-19 } \\
\text { infection }\end{array}$ & Find, identify, list, show, state \\
\hline
\end{tabular}


Beyond this primary goal of assessment, Boud and Soler (2015) proposed the notion of sustainable assessment. It aims to prepare students to develop learning spirit for the future and empower them with knowledge and skills that will allow them to operate successfully in a complex and challenging society (Baird et al., 2017; Boud, 2000; James, 2017). Sustainable assessment contributes to training students to become self-managing people, who, in collaboration with others, "can draw on whatever they need to continue learning effectively beyond the end of the course and be able to make judgments about their learning outcomes" (Boud \& Soler, 2015, p. 3). Sustainable assessment thus promotes self-reflection, judgment, and readiness for practice. It boosts evaluation and prepares students for life-long learning in an unknown and unpredictable future (Nguyen \& Walker, 2016).

In a dynamic and demanding world, knowledge and information retrieval, as an outcome of education, are no longer sufficient to produce the type of citizens that countries need to cope with economic, social, and technological changes (Assaly \& Smadi, 2015). Thus, sustainable assessment does not focus on content knowledge and generating grades but rather on ensuring that relevant and meaningful learning occurs (Bramwell-Lalor, 2018). In other words, assessments should prepare students for life-long learning (Nguyen \& Walker, 2016). Hence, with rapid development in digital technologies that are growing, education is forced to shift from knowledge acquisition in class to empowering learners with HOTs to prepare them to compete globally and succeed in the twenty-first century (Dall et al., 2018; Pendergast \& Swain, 2013; Ross, 2018).

\section{Methods}

For the purpose of this article, we used The Primary Leave English Examinations (PLEEs) as the study materials. We investigated the PLEEs that the REB has written and administered for 7 years, from 2013 to 2019. We collected data through the content analysis methodology. This approach is used to identify, organize, and analyze occurrences of specific messages included in texts. With the content analysis approach, the analysis unit is the smallest item on which researchers focus. It is supposed to bear minimal information responding to one or a series of research questions (Erlingsson \& Brysiewicz, 2017; Yanovitzky \& Weber, 2020). According to Titscher et al. (2012), "the units of analysis are the smallest components of texts in which the occurrence and the characterization of variables (properties, categories) are examined" (p. 58). An analysis unit can be a single word, a structure, a syntactic construction, or a theme (Titscher et al., 2012). In the framework of this study, the analysis units are action verbs used in association with one of the revised Bloom's taxonomy six cognitive levels.

First, in efforts to answer the research question, we identified, listed, and analyzed question stems based on each of the cognitive level and action verbs referring to the lower or higher thinking order of the revised Bloom's taxonomy. To do so, we developed a checklist based on Bloom's taxonomy six cognitive domains (Assaly \& Smadi, 2015; Atiullah et al., 2019). The checklist included a table with nine columns comprising the cognitive levels (higher and lower), the six cognitive domains, and action verbs used in each exam section for each of the 7 years of exam administration (2013-2019). Each exam paper included four areas, namely comprehension, grammar, vocabulary, and composition. We obtained a copy of the seven national PLEEs that we used to identify and analyze the questions. We found 574 questions that we scrutinized to investigate the degree to which the PLEEs addressed both higher and lower cognitive levels of the revised Bloom's taxonomy.

Second, we combined the checklist with an explanatory table that contained the cognitive levels, the six cognitive domains, definitions, examples, and illustrative action verbs. We used the table to quickly and accurately decide the cognitive domains used in the exam questions. We coded these action verbs of the cognitive part for each level: (1) remembering; (2) understanding; (3) applying (4); analyzing (5); evaluating; (6) creating.

Third, after coding exam questions according to the six cognitive domains, we recorded and presented data in tables. We provided frequencies for each school year, cumulative summation of questions in each of the six cognitive domains over 7 years, and related percentages for the 7 years of exams. We employed Microsoft Excel to perform those computations and analyze cognitive levels. Finally, we drew the comparative information using tables indicating frequencies and percentages, as illustrated in Tables 2-5.

\section{Findings}

As captured in Tables 2-5, we displayed frequencies and percentages followed by sample questions to illustrate the pattern of HOTS and LOTS found in the four sections of the national PLEEs.

\section{Revised Bloom's taxonomy in comprehension exam questions}

In Table 2, we note frequencies and percentages of cognitive levels employed in comprehension exam questions.

In this section, most questions are related to the lower thinking domain levels of remembering, understanding, and applying that make up the total percentage of $94.96 \%$, 
Table 2 Frequencies and percentages of the six levels of the cognitive domain in the revised Bloom's taxonomy in comprehension questions

\begin{tabular}{|c|c|c|c|c|c|c|c|c|c|c|}
\hline \multirow{2}{*}{$\begin{array}{l}\text { Cognitive } \\
\text { domain levels }\end{array}$} & \multirow[t]{2}{*}{ Cognitive domains } & \multicolumn{8}{|c|}{ Frequencies per school year } & \multirow[t]{2}{*}{ Percentages } \\
\hline & & 2013 & 2014 & 2015 & 2016 & 2017 & 2018 & 2019 & Total questions & \\
\hline \multirow[t]{4}{*}{ High order } & Creating & 0 & 0 & 0 & 0 & 0 & 0 & 0 & 0 & 0.00 \\
\hline & Evaluating & 0 & 0 & 0 & 0 & 0 & 0 & 0 & 0 & 0.00 \\
\hline & Analyzing & 0 & 0 & 0 & 0 & 0 & 0 & 0 & 0 & 0.00 \\
\hline & Applying & 0 & 0 & 0 & 0 & 0 & 0 & 1 & 1 & 0.84 \\
\hline \multirow[t]{2}{*}{ Low order } & Understanding & 0 & 3 & 2 & 0 & 0 & 0 & 0 & 5 & 4.20 \\
\hline & Remembering & 13 & 14 & 16 & 23 & 12 & 16 & 19 & 113 & 94.96 \\
\hline Total & & 13 & 17 & 18 & 23 & 12 & 16 & 20 & 119 & 100.00 \\
\hline
\end{tabular}

$4.20 \%$, and $0.84 \%$ respectively. As illustrated in Table 2, there was no question pertaining to the higher-order thinking levels. Sample questions from the comprehension section are presented below:

- Answer these questions using full sentences.

- Choose true or false.

- How is this story important to you as a student?

- Match the term with their meanings according to the passage.

- What type of foods should people not eat?

- Write three measures of controlling diseases in our community.

\section{Revised Bloom's taxonomy in grammar exam questions}

Apart from five questions that emerged from the analyzing domain of the higher-order cognition level, Table 3 indicates that the majority of the questions in this section come from the three lower-order cognitive levels, namely remembering, understanding, and applying.

As shown in Table 3, the trend from 2013 to 2019 indicates that grammar exam questions overwhelmingly covered the low order thinking levels of remembering $(80.69 \%)$, applying (16.55\%), and understanding (1.03\%). A marginal percentage $(1.72 \%)$ of questions came from one higher cognition level (analyzing). Moreover, the percentage of remembering questions $(80.69 \%)$ is higher than that of applying level $(16.55 \%)$ and almost five times greater than applying and understanding levels combined. Sample questions illustrating the four cognitive levels are listed below:

- Fill in the gaps with the simple past tense.

- I had breakfast then I went to school. (Rewrite using: ........ after .........).

- Make the following sentences singular.

- Organize each set of words into a meaningful sentence.

- Write the correct word from those given below for each statement.

\section{Revised Bloom's taxonomy in vocabulary exam questions}

Table 4 illustrates that there are only five questions pertaining to the applying domain of the lower-order cognition level. The rest of the questions in this section come from the lowest order level, that is remembering.

As displayed in Table 4, vocabulary exam questions covered only the two low order thinking levels of remembering $(96.93 \%)$ and applying $(3.07 \%)$. Similar to the grammar part, the vocabulary section lacks higher-order thinking questions. Additionally, it is worth noting a large percentage of remembering questions (96.93\%) against a

Table 3 Frequencies and percentages of the six levels of the cognitive domain in the revised Bloom's taxonomy in grammar questions

\begin{tabular}{|c|c|c|c|c|c|c|c|c|c|c|}
\hline \multirow{2}{*}{$\begin{array}{l}\text { Cognitive } \\
\text { domain levels }\end{array}$} & \multirow[t]{2}{*}{ Cognitive domains } & \multicolumn{8}{|c|}{ Frequencies per school year } & \multirow[t]{2}{*}{ Percentages } \\
\hline & & 2013 & 2014 & 2015 & 2016 & 2017 & 2018 & 2019 & Total questions & \\
\hline \multirow[t]{4}{*}{ High order } & Creating & 0 & 0 & 0 & 0 & 0 & 0 & 0 & 0 & $0.00 \%$ \\
\hline & Evaluating & 0 & 0 & 0 & 0 & 0 & 0 & 0 & 0 & $0.00 \%$ \\
\hline & Analyzing & 0 & 0 & 5 & 0 & 0 & 0 & 0 & 5 & $1.72 \%$ \\
\hline & Applying & 10 & 10 & 0 & 20 & 0 & 0 & 8 & 48 & $16.55 \%$ \\
\hline \multirow[t]{2}{*}{ Low order } & Understanding & 0 & 0 & 0 & 0 & 3 & 0 & 0 & 3 & $1.03 \%$ \\
\hline & Remembering & 30 & 25 & 60 & 30 & 37 & 30 & 22 & 234 & $80.69 \%$ \\
\hline Total & & 40 & 35 & 65 & 50 & 40 & 30 & 30 & 290 & $100.00 \%$ \\
\hline
\end{tabular}


Table 4 Frequencies and percentages of the six levels of the cognitive domain in the revised Bloom's taxonomy in vocabulary questions

\begin{tabular}{|c|c|c|c|c|c|c|c|c|c|c|}
\hline \multirow{2}{*}{$\begin{array}{l}\text { Cognitive } \\
\text { domain levels }\end{array}$} & \multirow[t]{2}{*}{ Cognitive domains } & \multicolumn{8}{|c|}{ Frequencies per school year } & \multirow[t]{2}{*}{ Percentages } \\
\hline & & 2013 & 2014 & 2015 & 2016 & 2017 & 2018 & 2019 & Total questions & \\
\hline \multirow[t]{4}{*}{ High order } & Creating & 0 & 0 & 0 & 0 & 0 & 0 & 0 & 0 & 0.00 \\
\hline & Evaluating & 0 & 0 & 0 & 0 & 0 & 0 & 0 & 0 & 0.00 \\
\hline & Analyzing & 0 & 0 & 0 & 0 & 0 & 0 & 0 & 0 & 0.00 \\
\hline & Applying & 0 & 0 & 0 & 0 & 0 & 5 & 0 & 5 & 3.07 \\
\hline \multirow[t]{2}{*}{ Low order } & Understanding & 0 & 0 & 0 & 0 & 0 & 0 & 0 & 0 & 0.00 \\
\hline & Remembering & 30 & 30 & 13 & 10 & 30 & 25 & 20 & 158 & 96.93 \\
\hline Total & & 30 & 30 & 13 & 10 & 30 & 30 & 20 & 163 & $100.00 \%$ \\
\hline
\end{tabular}

Table 5 Frequencies and percentages of the six levels of the cognitive domain in the revised Bloom's taxonomy in composition

\begin{tabular}{lllllllllllr}
\hline $\begin{array}{l}\text { Cognitive } \\
\text { domain } \\
\text { levels }\end{array}$ & Cognitive domains & \multicolumn{9}{l}{ Frequencies per school year } & Percentages \\
\cline { 3 - 10 } & & 2013 & 2014 & 2015 & 2016 & 2017 & 2018 & 2019 & $\begin{array}{r}\text { Total } \\
\text { ques- } \\
\text { tions }\end{array}$ \\
\hline High order & Creating & 0 & 0 & 0 & 0 & 0 & 1 & 1 & 2 & 100.00 \\
& Evaluating & 0 & 0 & 0 & 0 & 0 & 0 & 0 & 0 & 0.00 \\
& Analyzing & 0 & 0 & 0 & 0 & 0 & 0 & 0 & 0 & 0.00 \\
& Applying & 0 & 0 & 0 & 0 & 0 & 0 & 0 & 0 & 0.00 \\
Low order & Understanding & 0 & 0 & 0 & 0 & 0 & 0 & 0 & 0 & 0.00 \\
& Remembering & 0 & 0 & 0 & 0 & 0 & 0 & 0 & 0 & 0.00 \\
\hline \multirow{2}{*}{ Total } & & 0 & 0 & 0 & 0 & 0 & 1 & 1 & 2 & 100.00 \\
\hline
\end{tabular}

minimal number (3.07\%) of questions that emerged from the applying domain. Here are sample questions formulated as follows:

- Choose the correct answers and complete the sentences.

- Fill the following gaps with the correct word from the list below.

- Give the opposites of the following adjectives.

- Match the words in side A to their synonyms in side B using arrows.

- Use the words in the box to complete the story.

- Write down the abbreviations for the following words.

\section{Revised Bloom's taxonomy in composition exam questions}

Two levels of thinking domains come out of six in the composition exam questions. Table 5 portrays the frequencies and related percentages of the identified cognitive levels.

The findings obtained for composition exam questions indicate the occurrence of one higher-order cognition level, namely the creating domain with only two questions. As can be noted from Table 5, there is no exam question pertaining to the other remaining five cognitive levels. The two questions exemplifying the creating themes are mentioned below:
Table 6 Frequencies and percentages of the six levels of the cognitive domain in the revised Bloom's taxonomy in the exam questions for 7 years

\begin{tabular}{lllc}
\hline $\begin{array}{l}\text { Cognitive } \\
\text { domain levels }\end{array}$ & Cognitive domains & Frequencies & Percentages \\
\hline High order & Creating & 2 & 0.34 \\
& Evaluating & 0 & 0.00 \\
& Analyzing & 5 & 0.87 \\
& Applying & 54 & 9.40 \\
Low order & Understanding & 8 & 1.39 \\
& Remembering & 505 & 88.00 \\
Total & & 574 & 100.00 \\
\hline
\end{tabular}

- Choose one topic and write a composition of about 150 to 200 words in the space below.

- Choose one question and write a story of not more than 100 words.

\section{Revised Bloom's taxonomy in exam questions for 7 years}

Table 6 presents the frequencies and percentages of cognitive levels in all sections of exam questions for seven years from 2013 to 2019. 
As depicted in Table 6, a remarkable percentage of exam questions (98.79\%) relates to the lower-order thinking skills in total. It is notable that remembering as the lowest thinking order level has the highest portion $(88.00 \%)$ of the exam questions in the four exam sections. Both understanding and applying levels put together occupy the share of $10.79 \%$. Conversely, as low as $1.21 \%$ of exam questions pertain to the higher-order cognition levels.

\section{Discussion}

The study aimed to investigate the degree to which the REB considered both lower and higher thinking levels in the questions found in the national Primary Leaving English Examinations (PLEEs) from 2013 to 2019. The analysis of 574 exam questions reveals the immense prevalence of questions that emerged from the three LOTS domains (remembering, understanding, and applying). It stands out that the remembering domain, as the lowest level, is more dominant in all sections of exam questions $(88.00 \%)$ whereas both analyzing and creating domains of the HOTS levels occupy a very small number of exam questions (1.21\%). Overall, as depicted in Table 5, across the four exam sections for 7 years, the national PLEE questions predominantly come from the LOTS rather than the HOTS domains. The reason behind the prevalence of the LOTS processes in the national English exam questions is likely due to three factors, namely general consideration of the learning objectives, the EFL context, and situational factors related to curricular reforms and language educational policies in Rwanda.
In general, there is a tendency of giving a paramount importance and special attention to the knowledge and remembering domains (Tikhonova \& Kudinova, 2015; Tsaparlis, 2020). According to Krathwohl (2002), knowledge and comprehension are frequently considered the foundation to all the other education objectives (Chmielewska \& Gilanyi, 2018). Comprehension and information retrieval are a pre-requisite for in-depth understanding of more complex thinking activities, which is probably the reason why the LOTS are the most frequent intellectual ability to be focused on in upper primary levels. In the same lines of thoughts, the individual's knowledge increase is conducive to the development of the individual's better grasp, interpretation, and evaluation of the world around them. As Zareian et al. (2015) claimed, "Higher-order processes such as evaluating and creating must be based upon previous knowledge of our realities, which is, what we remember" ( $p$. 315). Hence, examiners and instructors may be inclined to include more LOTS than HOTS exams questions because they believe learners need to build stronger foundations to these lower-order thinking processes at an earlier age so that they can move on to schemata that are more complex later (Tikhonova \& Kudinova, 2015).

Furthermore, as displayed in Table 7 , in addition to this study, five published articles indicate a common trend of a high frequency of lower-order cognitive processes in EFL textbooks and assessment practices from the primary (elementary) to the university level because students' proficiency levels might be low. As sample studies in Table 7 illustrate, there is an average of $78.7 \%$ of LOTS questions versus a small portion of $21.3 \%$ of HOTS exam questions in primary school. Similarly, there is higher predominance

Table 7 Level of use of HOTS and LOTS in exam questions and textbooks

\begin{tabular}{|c|c|c|c|c|}
\hline \multirow[t]{2}{*}{ Country } & \multirow[t]{2}{*}{ Materials analyzed } & \multirow[t]{2}{*}{ Level } & \multicolumn{2}{|c|}{$\begin{array}{l}\text { Percentage of cognitive levels found in exam ques } \\
\text { tions and textbooks }\end{array}$} \\
\hline & & & $\begin{array}{l}\text { Lower-order thinking } \\
\text { cognitive questions (\%) }\end{array}$ & $\begin{array}{l}\text { Higher-order thinking } \\
\text { cognitive questions } \\
(\%)\end{array}$ \\
\hline Rwanda & $\begin{array}{l}\text { National English primary six leaving examina- } \\
\text { tions (primary data from this current study) }\end{array}$ & Primary six (sixth grade) & 98.79 & 1.21 \\
\hline Iran & $\begin{array}{l}\text { English textbooks: } \\
\text { (Riazi \& Mosalanejad, 2010) }\end{array}$ & $\begin{array}{l}\text { Senior high school and pre- } \\
\text { university }\end{array}$ & 73 & 27 \\
\hline Israel & $\begin{array}{l}\text { WH questions of English textbook Horizons: } \\
\text { (Igbaria, 2013) }\end{array}$ & High school & 64.04 & 35.96 \\
\hline Israel & $\begin{array}{l}\text { Reading Master Class textbook: } \\
\text { (Assaly \& Smadi, 2015) }\end{array}$ & High school & 60 & 40 \\
\hline Iran & $\begin{array}{l}\text { Interchange textbooks: } \\
\text { (Razmjoo \& Kazempourfard, 2012) }\end{array}$ & Universities & 82.86 & 17.14 \\
\hline Iran & $\begin{array}{l}\text { Textbooks: } \\
\text { (Davoudi et al., 2015) }\end{array}$ & Universities & 93.5 & 6.5 \\
\hline Average & & & 78.7 & 21.3 \\
\hline
\end{tabular}


of LOTS in assessment practices and textbooks at the university level. Thus, it is assumed that students do not have a good command of the English language that would enable them to tackle HOTS activities (Lee \& Wallace, 2017; Margana \& Widyantoro, 2017).

Major factors underlying EFL students' low English language proficiency include, but are not limited to, teachers' training and proficiency, curriculum, student motivation and engagement, limited exposure to English, and lack of practice outside the classroom, as well as the social context and school environment (Alharbi, 2015; Al-Mahrooqi, 2012; Escudero et al., 2020; Hung, 2019). As a result, both instructors and national examination boards may tend to include more LOTS than HOTS exam questions. They suppose students' low proficiency level may hinder them from attempting exam questions that require complex cognitive processes as described in the HOTS categories.

\section{Implications for educational and assessment practices}

According to the study findings, there is an overwhelming prevalence of the LOTS (98.79\%) over the HOTS $(1.21 \%)$ exam questions. Such an unbalance of questions based on the six cognitive domains in the national examinations may lead to the negative impact of the washback effect on instructional quality and student learning.

\section{The impact of high-stake national exams on teaching and learning quality}

Abundant research revealed assessment could influence teaching and learning quality (Kulasegaram \& Rangachari, 2018; Wanner \& Palmer, 2018). As Darling-Hammond and Rustique-Forrester (2005) pointed out, "tests can drive instruction in ways that mimic not only the content, but also the format and cognitive demands of tests" (p. 3). Scholarship indicates that well-organized and thoughtfully written assessments could enhance the quality of teaching and student learning. These types of assessment described above are likely to improve instruction because they offer challenging and thought-provoking tasks both for teachers to prepare and for students to aspire to. This type of assessment will also drive teacher professional learning in their continuous improvement efforts (Darling-Hammond \& Rustique-Forrester, 2005; Mayes et al., 2020; Wanner \& Palmer, 2018).

On the contrary, literature contends assessment might have negative effects on teaching quality and student learning and performance when instruction and assessment do not focus on complex reasoning, critical analysis, and creativity, as was the case in the national PLEEs. In the same vein, studies suggest that teachers tend to teach to the test under the pressure of accountability of showing high student achievement, and in some worst-case scenarios, they teach the test. They spend significant instructional time on exercises that look exactly like the exam items. They pay special attention to instructional methods such as remembering and recitation to better prepare students for national exams. National and high-stake exam-oriented accountability has been proven detrimental to instructional strategies that promote the teaching of complex reasoning, critical thinking, and problem-solving skills (Darling-Hammond \& RustiqueForrester, 2005; Ryan \& Henderson, 2017; Wilson, 2018).

Additionally, when teachers are more concerned with national exams their students will take, teachers will adjust their instruction to cover specific exam items instead of considering the entire curriculum or at least the priority domains from which those exam questions come from (Darling-Hammond \& Rustique-Forrester, 2005; Kuang, 2020). In this vein, when decision-makers use student scores for student promotions and teacher evaluation purposes, "teachers feel pressured to use test formats in their instruction and to teach in ways that contradict their ideas of sound instructional practice" (Darling-Hammond \& Rustique-Forrester, 2005, p. 13).

Consequently, the fact that students spend more instruction time preparing for the exam or studying past exams that are highly LOTS-driven can impede the acquisition of survival skills, as described in the curriculum books. Thus, students will miss the mastery of complex reasoning skills as stipulated in the curriculum. When primary education does not consider critical thinking instruction and sustainable assessment, students are likely to face challenges in secondary and tertiary education as well as their personal and professional lives.

In the same vein, Pendergast and Swain (2013) underscored the importance of HOTS over LOTS because higher cognitive abilities challenge students to process, manipulate, and evaluate new information, which is critical for success in the twenty-first century. On the contrary, lower-order thinking focuses only on simple recall or identification of previously acquired knowledge such as reproducing and enumerating information previously memorized.

\section{Limitations and future research}

The qualitative study was the first empirical research to examine the assessment practices in primary education after the swift switch from French to English as the classroom language in 2008 and the implementation of the CBC in replacement of the knowledge-based curriculum in 2015. However, the study focused on the Primary Leaving English Examinations only. It would be better to look at national 
English examinations administered in the entire 12-year basic education system. This would deepen the understanding of the national education system regarding the effective and thoughtfully structured assessment approaches in alignment with the CBC content. Moreover, the study used a content analysis methodology that simply investigated sample national English examinations. Further inquiries should be extended to English textbooks used both in lower and upper primary education. Moreover, it would be useful to look into REB staff and teachers' perceptions of the assessment practices in schools.

\section{Conclusion}

According to the findings, before the CBC implementation (2013-2015), it is noticeable that there were no exam questions categorized in the higher-order thinking levels. The rollout of the CBC from 2016-2019 does not seem to change the scenery because slight and insignificant changes were noticeable in the number of HOTS exam questions. There was a meager percentage of HOTS exam questions from the creating domain $(0.34 \%)$.

Such findings do not support the government's vision of developing a skilled citizenry through high-quality education driven by a competence-based curriculum. Scholarship in teaching English as a foreign language (EFL) suggested that the cognitive level used in assessment activities plays a pivotal role in linguistic and communicative competence development and mastery (Igbaria, 2013). Therefore, exam questions should be of various levels so that students can gain the competencies they need to succeed in school and life.

Undoubtedly, no one can claim that all questions on exams should be high level. Indeed, factual questions are important because students need to know certain basic information before engaging in higher-order thinking. Low-level cognitive questions increase the acquisition of accurate knowledge and pave the way for acquiring highcognitive skills. However, high-level questions are practical tools for prompting and promoting thinking and improving other cognitive skills like problem solving and decisionmaking. Higher-order thinking skills are more challenging to learn, teach, and assess, but they are also vital because such skills are likely to be usable in novel situations. Beyond memorization and information retrieval, HOTS enable learners to become creative thinkers passionate about discovering, imagining, designing, inventing, and producing (Thomas \& Thorne, 2009). Therefore, to meet this objective, Rwandan educational services should design teaching methods and assessment materials that reflect the outcomes as described in the curriculum and assess the expected standards (Alfauzan \& Tarchouna, 2017; Pendergast \& Swain, 2013; Sibomana, 2016).

\section{References}

Akala, B. M. (2021). Revisiting education reform in Kenya: A case of competency based curriculum (CBC). Social Sciences \& Humanities Open, 3(1), 100-107. https://doi.org/10.1016/j.ssaho.2021. 100107

Alfauzan, A. A., \& Tarchouna, N. (2017). The role of an aligned curriculum design in the achievement of learning outcomes. Journal of Education and e-Learning Research, 4(3), 81-91.

Alharbi, H. A. (2015). Improving students' English speaking proficiency in Saudi public schools. International Journal of Instruction, 8(1), 105-116.

Al-Khayyat, A. S. J. (2020). Investigating the level of Bloom's cognitive verbs included in Baccalaureate English language exams in Iraq. Journal of University of Shanghai for Science and Technology, 22(11), 118-125.

Al-Mahrooqi, R. (2012). A student perspective on low English proficiency in Oman. International Education Studies, 5(6), 263-271.

Anderson-Levitt, K. (2017). Global flows of competence-based approaches in primary and secondary education. Cahiers De La Recherche Sur L'éducation Et Les Savoirs, 16, 47-72.

Andrade, H. L., \& Brookhart, S. M. (2020). Classroom assessment as the co-regulation of learning. Assessment in Education: Principles, Policy \& Practice, 27(4), 350-372.

Armstrong, P. (2010). Bloom's taxonomy. Vanderbilt University. Retrieved December 13, 2021 from https://cft.vanderbilt.edu/ guides-sub-pages/blooms-taxonomy/

Arvianto, Z. I., Faridi, A., \& Zuchdy, D. (2020). The compatibility between philosophy basis of 'English in Mind' textbook and curriculum 2013. VELES Voices of English Language Education Society, 4(2), 163-176.

Assaly, I. R., \& Smadi, O. M. (2015). Using Bloom's taxonomy to evaluate the cognitive levels of master class textbook's questions. English Language Teaching, 8(5), 100-110.

Atiullah, K., Fitriati, S. W., \& Rukmini, D. (2019). Using revised Bloom's taxonomy to evaluate higher order thinking skills (Hots) in reading comprehension questions of English textbook for year X of High School. English Education Journal, 9(4), 428-436.

Bahati, B., Tedre, M., Fors, U., \& Mukama, E. (2016). Exploring feedback practices in formative assessment in Rwandan higher education: A multifaceted approach is needed. International Journal of Teaching \& Education, 4(2), 1-22.

Baird, J.-A., Andrich, D., Hopfenbeck, T. N., \& Stobart, G. (2017). Assessment and learning: Fields apart? Assessment in Education: Principles, Policy \& Practice, 24(3), 317-350.

Boud, D. (2000). Sustainable assessment: Rethinking assessment for the learning society. Studies in Continuing Education, 22(2), $151-167$.

Boud, D., \& Soler, R. (2015). Sustainable assessment revisited. Assessment \& Evaluation in Higher Education, 41(3), 400-413.

Bramwell-Lalor, S. (2018). Assessment for learning on sustainable development. In W. L. Filho (Ed.), Encyclopedia of Sustainability in Higher Education (pp. 1-9). Springer, Cham. https://doi.org/ 10.1007/978-3-319-63951-2_1-1

Chmielewska, K., \& Gilanyi, A. (2018). Educational context of mathability. Acta Polytechnica Hungarica, 15(5), 223-237.

Christensen, N. \& Lane, J. (2016). Know-do-understand: Development of competencies in Canada's schoolchildren. Canada West Foundation, Center for Human Capital Policy. Retrieved 
December 11, 2021 from http://cwf.ca/wp-content/uploads/ 2016/03/HCP_KnowDoUnderstand_Report_MARCH2016-2. pdf

Costin, C. \& Pontual, T. (2020). Curriculum reform in Brazil to develop skills for the twenty-first century. In F.M. Reimers (ed.), Audacious education purposes. How governments transform the goals of education systems (pp. 47-64). Springer Open

Daggett, W. R. (2016). A guide to focusing resources to increase student performance. International Center for Leadership in Education. Retrieved December 29, 2021 from https://leadered.com/wpcontent/uploads/rigorrelevance-framework-professional-paper.pdf

Dall, I., Dickson, D., Payne, R., \& Tierney, S. (2018). Transforming education: Empowering the students of today to create the world of tomorrow. Microsoft. com. Retrieved December 29, 2021 from https://news.microsoft.com/wpcontent/uploads/prod/sites/66/ 2018/06/Transforming-Education-eBook_Final.pdf

Darling-Hammond, L., \& Rustique-Forrester, E. (2005). The consequences of student testing for teaching and teacher quality. Yearbook of the National Society for the Study of Education, 104(2), 289-319.

Deller, J. (2019). Bloom's taxonomy levels of learning: The complete post. Kodo survey. Retrieved December 1, 2021 from https:// kodosurvey.com/blog/blooms-taxonomy-levels-learning-compl ete-post

Dlamini, B. S., Bhebhe, S., \& Dlamini, P. A. (2018). The unfolding competency-based education process in Swaziland 2010-2017. IOSR Journal of Humanities and Social Science (IOSR-JHSS), 23(2), 27-41. https://doi.org/10.9790/0837-2302052741

Elshawa, N., Heng, C. S., Abdullah, A. N., \& Rashid, S. (2016). Teachers' assessment literacy and washback effect of assessment. International Journal of Applied Linguistics and English Literature, $5(4), 1-7$

Erlingsson, C., \& Brysiewicz, P. (2017). A hands-on guide to doing content analysis. African Journal of Emergency Medicine, 7(3), 93-99.

Escudero, G. I., Cutiopala, D. J., \& Caisaguano, J. A. (2020). A comprehensible overview of EFL students' drawbacks to produce oral communication. Revista ESPACIOS, 41(18), 1-12.

Euromonitor International. (2010). The benefits of the English language for individuals and societies: Quantitative indicators from Cameroon, Nigeria, Rwanda, Bangladesh and Pakistan. Retrieved November 5, 2021 from http://www.teachingenglish.org.uk/sites/ teacheng/files/Euromonitor Report A4.pdf

Freahat, N. M., \& Smadi, O. M. (2014). Lower-order and higher-order reading questions in secondary and university level EFL textbooks in Jordan. Theory and Practice in Language Studies, 4(9), 1804-1813.

Gottipati, S., \& Shankararaman, V. (2017). Competency analytics tool: Analyzing curriculum using course competencies. Education and Information Technologies, 23(1), 41-60.

Government of Rwanda. (2020). Social transformation. Republic of Rwanda. Retrieved November 1, 2021 from https://www.gov.rw/ highlights/social-transformation

Hung, B. P. (2019). A cognitive linguistic approach to teaching English idioms to EFL students: Experimental results. 3L: The Southeast Asian Journal of English Language Studies, 25(2), 113-126.

Igbaria, A. K. (2013). A content analysis of the WH-questions in the EFL textbook of" Horizons". International Education Studies, 6(7), 200-224.

James, M. (2017). (Re)viewing assessment: Changing lenses to refocus on learning. Assessment in Education: Principles, Policy \& Practice, 24(3), 404-414.

Jones, K. O., Harland, J., Reid, J. M., \& Bartlett, R. (2009). Relationship between examination questions and Bloom's taxonomy. 2009 39th IEEE Frontiers in Education Conference. Retrieved December 29, 2021 from https://ieeexplore.ieee.org/document/5350598
Kafyulilo, A. C., Rugambuka, I. B., \& Moses, I. (2013). Implementation of competency based teaching in Morogoro Teachers' Training College, Tanzania. Makerere Journal of Higher Education, 4(2). https://doi.org/10.4314/majohe.v4i2.13

Kayigema, J. L., \& Mutasa, D. E. (2014). The cohabitation of three official languages in post-genocide Rwanda: Kinyarwanda, English and French. South African Journal of African Languages, $34(2), 235-245$.

Koç, E., \& Öntaş, T. (2020). A comparative analysis of the 4th and 5th grade social studies curriculum according to revised Bloom taxonomy. Cypriot Journal of Educational Sciences, 15(3), 540-553.

Köksal, D., \& Ulum, Ö. G. (2018). Language assessment through Bloom's taxonomy. Journal of Language and Linguistic Studies, 14(2), 76-88.

Komba, S. C., \& Mwandaji, M. (2015). Reflections on the implementation of competence-based curriculum in Tanzanian secondary schools. Journal of Education and Learning, 4(2). https://doi.org/ 10.5539/jel.v4n2p73

Krathwohl, D. R. (2002). A revision of Bloom's taxonomy: An overview. Theory into Practice, 41(4), 212-218.

Krikorian, L. (2019). The Singapore of Africa? Polemics. Retrieved October 13, 2021 from http://www.polemics-magazine.com/econ/ rwanda-economic-miracle

Kuang, Q. (2020). A review of the washback of English language tests on classroom teaching. English Language Teaching, 13(9), 10-17.

Kulasegaram, K., \& Rangachari, P. K. (2018). Beyond "formative": Assessments to enrich student learning. Advances in Physiology Education, 42(1), 5-14.

Lee, G., \& Wallace, A. (2017). Flipped learning in the English as a foreign language classroom: Outcomes and perceptions. TESOL Quarterly, 52(1), 62-84.

Makunja, G. (2016). Challenges facing teachers in implementing competence-based curriculum in Tanzania: The case of community secondary schools in Morogoro Municipality. International Journal of Education and Social Science, 3(5), 1-8.

Margana, M., \& Widyantoro, A. (2017). Developing English textbooks oriented to higher order thinking skills for students of vocational high schools in Yogyakarta. Journal of Language Teaching and Research, 8(1), 26-38.

Mayes, E., Black, R., \& Finneran, R. (2020). The possibilities and problematics of student voice for teacher professional learning: Lessons from an evaluation study. Cambridge Journal of Education, 51(2), 195-212. https://doi.org/10.1080/0305764X.2020. 1806988

Mugisha, I. S. (2010). Assessment and study strategies: A study among Rwandan students in higher education [Unpublished doctoral dissertation]. Linköping University

Ndihokubwayo, K., Habiyaremye, T. H., \& Rukundo, J. C. (2019). Rwandan new competence base: Curriculum implementation and issues; Sector-based trainers. A Journal of Contemporary Research, 16(1), 24-41.

Ndihokubwayo, K., \& Habiyaremye, H. T. (2018). Why did Rwanda shift from knowledge to competence-based curriculum? Syllabuses and textbooks point of view. African Research Review, 12(3), 38-48.

Ndihokubwayo, K., Uwamahoro, J., \& Ndayambaje, I. (2020). Implementation of the competence-based learning in Rwandan physics classrooms: First assessment based on the reformed teaching observation protocol. EURASIA Journal of Mathematics, Science and Technology Education, 16(9), 1-8.

Ngendahayo, E., \& Askell-Williams, H. (2016). Rwanda's new competence-based school curriculum. Publishing Higher Degree Research, 155-165

Nguyen, T. T., \& Walker, M. (2016). Sustainable assessment for lifelong learning. Assessment \& Evaluation in Higher Education, 41(1), 97-111. 
Nsengimana, V. (2021). Implementation of competence-based curriculum in Rwanda: Opportunities and challenges. Rwandan Journal of Education, 5(1), 129-138.

Nykowanna, S. (2019). Teacher professional development and the seven $21^{\text {st }}$ Century survival skills: A program evaluation [Unpublished doctoral dissertation]. National Louis University

Ondimu, M. S. (2018). Teachers'preparedness for implementation of the competency based curriculum in private pre-schools in Dagoretti North sub county, Nairobi City County. MSc Thesis, University of Nairobi, Kenya

Pendergast, D., \& Swain, K. (2013). Competing interests? NAPLAN and middle schooling assessment practices. Australian Journal of Middle Schooling, 13(1), 4-17. https://search.informit.org/ doi/https://doi.org/10.3316/aeipt.212273

Pikhart, M., \& Klimova, B. (2019). Utilization of linguistic aspects of Bloom's taxonomy in blended learning. Education Sciences, 9(3), 235-244.

Rajandiran, D. (2021). Singapore's teacher education model for the 21st century (TE21). In F. M. Reimers (ed.). Implementing deeper learning and 21st century education reforms. Building an education renaissance after a global pandemic (pp. 59-77). Springer Nature.

Ramirez, T. V. (2017). On pedagogy of personality assessment: Application of bloom's taxonomy of educational objectives. Journal of Personality Assessment, 99(2), 146-152. https://doi.org/10.1080/ 00223891.2016.1167059

Rosell-Aguilar, F. (2017). State of the app: A taxonomy and framework for evaluating language learning mobile applications. CALICO Journal, 34(2), 243-258

Ross, D. (2018). Empowering our students with 21st-century skills for today. Getting Smart. Retrieved October 9, 2021 from https:// www.gettingsmart.com/2017/04/empowering-students-21st-centu ry-skills/

Ruth, C., \& Ramadas, V. (2019). The "Africanized" competency-based curriculum: The twenty-first century strides. Shanlax International Journal of Education, 7(4), 46-51. https://doi.org/10. 34293/education.v7i4.640

Rwanda Education Board. (2015a). Competence-based curriculum. Summary of curriculum framework. Pre-primary to upper secondary. Ministry of Education. Retrieved December 29, 2021 from https://mudarwan.files.wordpress.com/2015/08/curriculum_frame work_final_printed-compressed.pdf

Rwanda Education Board. (2015b). English language upper primary level P4-P6. Ministry of Education. Retrieved December 29, 2021 from https://docplayer.net/138124238-English-language-upperprimary-p4-p6-kigali-2015.html

Rwanda Education Board. (2019). The project for supporting institutionalizing and improving quality of SBI activity (SIIQS). Edline survey report. Japan International Cooperation Agency and PADECO CO., Ltd.

Ryan, J., Kang, C., Mitchell, I., \& Erickson, G. (2009). China's basic education reform: An account of an international collaborative research and development project. Asia Pacific Journal of Education, 29(4), 427-441.

Ryan, T., \& Henderson, M. (2017). Feeling feedback: Students' emotional responses to educator feedback. Assessment \& Evaluation in Higher Education, 43(6), 880-892.

Scheopner Torres, A., Brett, J., Cox, J., \& Greller, S. (2018). Competency education implementation: Examining the influence of contextual forces in three New Hampshire secondary schools. AERA Open, 4(2), 1-13.

Sibomana, E. (2016). The alignment between the Rwandan ordinary level national curriculum and national examinations for English: Lessons for examiners. Rwanda Journal Series B, 3(1), 63-76.

Sifuna, D. N., \& Obonyo, M. M. (2019). Competency-based curriculum in primary schools in Kenya. Prospects and challenges of implementation. Journal of Popular Education in Africa., $3(7), 39-50$.

Song, W. (2019). A study on the influence of teachers' questioning in high school English reading class on students' critical thinking. Theory and Practice in Language Studies, 9(4), 424-428.

Sundayana, W., Meekaeo, P., Purnawarman, P., \& Sukyadi, D. (2018). Washback of English national exams at ninth-grade level in Thailand and Indonesia. Indonesian Journal of Applied Linguistics, 8(1), 167-176.

Sydoruk, P. D. (2018). An analysis of the higher order thinking requirements of a grade 8 online-based English language arts skills program [Unpublished doctoral dissertation]. Seton Hall University

Tabaro, C. (2017). Assessment in Rwandan higher education: What is the situation at the University of Rwanda-College of Education? International Journal of Education and Research, 5(2), 273-286.

Tabaro, C. (2018). The Rwandan secondary school competence-based curriculum: Knowledge, skills and attitudes to incorporate in the University of Rwanda-College of Education programs to align them with the current curriculum. International Journal of Education and Practice, 6(2), 64-75.

The Learning Center. (2020). Higher order thinking: Bloom's taxonomy. Learning Center. Retrieved October 15, 2021 from https:// learningcenter.unc.edu/tips-and-tools/higher-order-thinking/

The World Bank \& Government of Rwanda. (2018). Future drivers of growth in Rwanda: Innovation, integration, agglomeration, and competition. World Bank. Retrieved December 29, 2021 from https://openknowledge.worldbank.org/handle/10986/30732

Thomas, A., \& Thorne, G. (2009). How to increase higher order thinking. Center for Development and Learning. Retrieved December 29, 2021 from https://www.readingrockets.org/article/how-incre ase-higher-order-thinking

Tikhonova, E., \& Kudinova, N. (2015). Sophisticated thinking: Lower order thinking skills. Proceedings of the 2 nd International Multidisciplinary Scientific Conferences on Social Sciences and Arts, (2), 352-360

Titscher, S., Meyer, M., Wodak, R., \& Vetter, E. (2012). Methods of text and discourse analysis. Sage publications. Retrieved December 29, 2021 from https://sk.sagepub.com/books/methods-of-text-anddiscourse-analysis

Tosuncuoglu, I. (2018). Importance of assessment in ELT. Journal of Education and Training Studies, 6(9), 163-167.

Tsaparlis, G. (2020). Higher and lower-order thinking skills: The case of chemistry revisited. Journal of Baltic Science Education, 19(3), 467-483.

Uğur, F. (2019). Evaluation of activities in secondary school level Turkish workbooks according to types of memory and revised Bloom's taxonomy. International Education Studies, 12(4), 185-197.

Wachiuri, D. R. N., Nonglait, B. S. L., \& Kimathi, J. N. (2017). To determine the effects of the role of examinations on the development of all-inclusive learners in secondary schools Nyeri County, Kenya. IOSR Journal of Research \& Method in Education (IOSRJRME), 07(03), 62-65.

Wagner, T. (2011). Rigor redefined. Tony Wagner. Retrieved September 29, 2021 from https://www.tonywagner.com/news/rigor-redef ined" https://www.tonywagner.com/news/rigor-redefined

Wang, T. (2019). Competence for students' future: Curriculum change and policy redesign in China. ECNU Review of Education, 2(2), 234-245. https://doi.org/10.1177/2096531119850905

Wanner, T., \& Palmer, E. (2018). Formative self-and peer assessment for improved student learning: The crucial factors of design, teacher participation and feedback. Assessment \& Evaluation in Higher Education, 43(7), 1032-1047.

Welch, A., Karpen, S., Brian Cross, L., \& LeBlanc, B. (2017). A multidisciplinary assessment of faculty accuracy and reliability 
with Bloom's taxonomy. Research \& Practice in Assessment, 12, 95-105.

Wilson, L. O. (2016). Anderson and Krathwohl Bloom's taxonomy revised. Quincy College. Retrieved August 7, 2021 from https:// quincycollege.edu/content/uploads/Anderson-and-Krathwohl_ Revised-Blooms-Taxonomy.pdf

Wilson, M. (2018). Making measurement important for education: The crucial role of classroom assessment. Educational Measurement: Issues and Practice, 37(1), 5-20.

Yanovitzky, I., \& Weber, M. (2020). Analysing use of evidence in public policymaking processes: A theory-grounded content analysis methodology. Evidence \& Policy: A Journal of Research, Debate and Practice, 16(1), 65-82.

Zareian, G., Davoudi, M., Heshmatifar, Z., \& Rahimi, J. (2015). An evaluation of questions in two ESP coursebooks based on Bloom's new taxonomy of cognitive learning domain. International Journal of Education and Research, 3(8), 313-326.

Zorluoglu, S. L., Kizilaslan, A., \& Yapucuoglu, M. D. (2020). The analysis of 9th grade chemistry curriculum and textbook according to revised Bloom's taxonomy. Cypriot Journal of Educational Sciences, 15(1), 9-20.

Publisher's Note Springer Nature remains neutral with regard to jurisdictional claims in published maps and institutional affiliations. 